\title{
Affinity in the Species of Paratylenchus (Tylenchida: Paratylenchidae)
}

\author{
Y. S. Rathore ${ }^{1}$, S. N. Tiwari ${ }^{2}$ \\ ${ }^{1}$ Indian Institute of Pulses Research, Kanpur 208 024, MIG 110, Indira Nagar, Kanpur 208026 (U.P.), India \\ ${ }^{2}$ G.B. Pant University of Agriculture and Technology, Pantnagar, Udham Singh Nagar, Uttarakhand, 263145, India
}

\begin{abstract}
Host taxonomic affinity of 28 species of Paratylechus was examined and it was observed that, in general, this nematode tend to share $65.79 \%$ host species from dicotyledons, $31.95 \%$ mocotyledons and $2.26 \%$ gymnosperms. Plants from lignosae division (fundamentally woody plants) contributed by $42.48 \%$ and herbaceae (fundamentally herbaceous plants) only $23.31 \%$, almost half of the lignosae. Among families Fabaceae (Lrguminales), Rosaceae (Rosales), and Vitaceae (Rhamnales) were more contributing in lignosae; Asteraceae (Asterales) and Lamiaceae (Lamiales) in herbaceae and Poaceae (Graminales) in glumiflorae of monocotyledons. Out of 28 species of Paratylechus, 12 were host specific or monophagous, 3 oligophagous and 13 polyphagous. Some of the polyphagous species feed on gymnosperms and on very primitive families of angiosperms.
\end{abstract}

Keywords: Nematode, Paratylenchus, Host range, Host taxonomic affinity

\section{Introduction}

Paratylenchus spp. are the smallest plant parasitic nematodes hence known as pin nematodes. They are migratory endoparasites [1] and have 4 juvenile stages. On hatching juveniles migrate towards plant roots. All feeding stages feed by inserting the stylet into epidermal cells and withdraw cellular contents. Symptoms may be localized lesions, offset root development, reduce epidermal surface area, disrupting absorptive efficiency of roots, reducing potential health and vigor of plants, patchy appearance in field crops and stunted plant growth. Paratylenchus is widely distributed and have more than 120 species [2]. Thorsteinson (1960)[3] was of the view that most of the insects feed on plants of certain taxonomic groups and others feed indiscriminately. Rathore and Lal (1998)[4] and Rathore and Tiwari (2014, 2015, 2015a) [5]-[7] observed the similar association in the case of pod bore, Maruca vitrata, Bemisia tabaci, many other species of Bemisia and three species of aphids, respectively. When same hypothesis was tested in other organisms like nematodes, the similar trend of host preference to plant taxonomic groups was reported by Rathore and Ali (2014)[8] in Meloidogyne incognita and Rathore and Tiwari (2015a, 2015b, 2016 ) [9]-[11] in Heterodera spp., Helicotylenchus spp. and Meloidogyne spp., respectively. Since Paratylenchus is very small in size and has different feeding behavior, host plant association was, therefore, tested in this nematode.

\section{Materials and Methods}

The species of Paratylenchus and their host plants were downloaded from internet [12] and from the literature [13]. All the host species were aligned to different families and orders by following the classification of Hutchinson (1973)[14]. He classified angiosperms (flowering plants) into two subphyla- dicotyledons and monocotyledons. Dicotyledons were partitioned in lignosae (fundamentally woody plants) and herbaceae (fundamentally herbaceous plants). Monocotyledons were divided into three divisions viz., calyciferae (distinct calyx and corolla), corolliferae (calyx and corolla are more or less similar) and glumiflorae (perianth is much reduced or represented by lodicules).To denote the closeness to a taxonomic group, General Association Index (GAI) reported by Rathore and Tiwari (2015 d)[11] was utilized and is given below:

General Association Index $(\mathrm{GAI})=\frac{\mathrm{THs}+2}{\mathrm{G}+\mathrm{F}+\mathrm{O}}$

Where, THs $=$ Total number of host plants of a given nematode species, $\mathrm{G}=$ Number of host genera, $\mathrm{F}=$ Number of host families, and $\mathrm{O}=$ Number of host orders. Value 1 indicates monophagy or where total of $\mathrm{G}+\mathrm{F}+\mathrm{O}$ is equivalent to no. of host species; values greater or less than 1 represents higher or lower affinity with taxonomic groups The terms monophagous, oligophagous and polyphagous were used as defined by Bernays and Chapman (1994) [15]. Monophagous utilizes hosts from some species of one genus, oligophagous selects plants from few genera of a single family and polyphagous feeds on plant species across the families and orders. The groups or clades formed on the basis of molecular studies were also discussed vis-à-vis to host taxonomic relationships.

\section{Results and Discussion}

Results on host preference and their affiliation of 28 species of Paratylenchus is presented in Table 1. Scanning of the data across the nematode species manifest that dicotyledons shared $65.79 \%$ plant species, whereas monocotyledons $31.95 \%$ and gymnosperms $2.26 \%$. Host plant belonging to lignosae (fundamentally woody plants) division of dicotyledons contributed $42.48 \%$ and herbaceae (fundamentally herbaceous plants) division only $23.31 \%$, i.e., almost half of the lignosae group. Among monocotyledons, the contribution of various divisions was 2.63, 1.88 and $27.44 \%$ of calyciferae, corolliferae and glumiflorae, respectively.

Among dicotyledons-lignosae families Fabaceae (Leguminales), Rosaceae (Rosales) and Vitaceae (Rhamnales) made up $19.17 \%$ of the total, while in 


\section{International Journal of Science and Research (IJSR) \\ ISSN (Online): 2319-7064 \\ Index Copernicus Value (2013): 6.14 | Impact Factor (2014): 5.611}

herbaceae $7.90 \%$ was due to Asteraceae (Asterales) and Lamiaceae (Lamiales). In monocotyledons it was 26.79\% due to Poaceae (Graminales). Though minimum but enough contribution was of families Pinaceae (Pinales) and Polypodiaceae (Polypodiales) of gymnosperms to sustain the nematode populations. The nematode species, in general, were aligned to these broad taxonomic groups.

Perusal of Table 1 also elucidate that out of 28 species of Paratylenchus, 12 were monophagous, 3 oligophagous and rest 13 polyphagous. Host specificity of monophagous species on host plants of dicotyledons-lignosae ( $P$. besoekianus on Rubiaceae (Rubiales), P. elachistus on Urticaceae (Urticales), $P$. nawadus on Apocynaceae (Apocynales), P. paraperaticus on Juglandaceae (Jugllandales), P. prunii on Rosaceae (Rosales), P. sheri on Fabaceae (Leguminales), P. straeleni on Moraceae (Urticales); 3 dicotyledons-herbaceae ( $P$. conicephalus and $P$. thornei on Apiaceae (Umbellales), P. halophilus on Chenopodiaceae (Chenopodiales), and 2 monocotyledons ( $P$. aquaticus on Bromeliaceae (Bromeliales), P. labiosus on Poaceae (Graminales). Host range of three oligophagous species was restricted within two families, i.e., P. amblycephalus on Rosaceae (Rosales), P. tatae and $P$. vexans on Poaceae (Graminales).

Among polyphagous species, $P$. dianthus, $P$. hamatus, $P$. macrophallus, $P$. nanus, $P$. neoamblyphalus and $P$. pojectus has a good host range and feed across the families and orders of various plant species. $P$. epacris and $P$. nainiacus restricted its preference to lignosae group of plants, whereas $P$. projectus was largely aligned towards herbaceae and Poaceae. P. hamatus parasitized large number of hosts from 19 orders in lignosae, 9 in herbaceae, 5 in monocotyledons and 2 in gymnosperms. This nematode species not only parasitize plants from very primitive families like Magnoliaceae (Magnoliales) and Lauraceae (Laurales) but also from Pinales and Polypodiales of gymnosperms. Present day flowering plants (angiosperms) evolved from gymnosperms long time ago. Short evolutionary linages were also evident in dicotyledons but with some missing links. These findings are in conformity with those of Rathore and Ali (2014)[8] and Rathore and Tiwari (2015 b,c,d) [9]-[11] for Heterodera spp., Helicotylenchus spp. and Meloidogyne spp., respectively.

Molecular study of van Megen et al (2009) [16] on construction of phylogenetic tree covering 15 nematode orders revealed that 4 Paratylenchus species (P. dianthus, $P$. microdorus. $P$. neoamblycephalus and P. straeleni are grouped in Clade 12. Affiliation to host species indicated that first three species are polyphagous and $P$. straeleni is monophagous and feeds on Ficus sp. of family Moraceae (Urticales). An elaborate study of Van den Berg et al (2014)[17] on phylogenetic relationships based on D2-D3 of 28S rRNA and ITS rRNA gene sequences revealed that $P$. aquaticus, $P$. hamatus and $P$. nanus represent species complex. However, a well resolved relationship was divided in to four clades. These authors also provided information as suggested by Geraert (1965) [18] on stylet length and valva position. The Clade $\mathrm{I}$ : included $P$. hamatus species complex, $P$. nanus (type A \& B), $P$. dianthus, $P$. minutus, $P$. Lepidus and Paratylenchus sp. 3, (stylet-19-36um, V-78-86); Clade II: Paratylechus sp. 5; Clade III: $P$. aculentus and P. bilineatus ( stylet-54-85 um, V- 68-79) and Clade IV: P. aquaticus (stylet- 10-19 um, $\mathrm{V}$-79-85). Our findings to corroborate host preference with clades are not clear except that most of the Paratylenchus species in Clade I are polyphagous. Only $P$. lepidus reported from rhizosphere of tea, Camellia sp. [19] is monophagous. We do not have information on species grouped in Clade II and III. $P$. aquaticus grouped in Clade IV is monophagous and parasitizes on Neoregelia sp. in family Bromeliaceae (Bromeliales). We also do not have sufficient information to substantiate but it appears that Paratylenchus species with long stylet are polyphagous. More information is required on species grouping in different clades.

\section{Acknowledgements}

Authors are grateful to Mr. Akhilesh Rathore for extending help in retrieving necessary information.

\section{References}

[1] Wikipedia (2015) Fig Pin Nematode. (en.wikipedia.org/wiki/Paratylenchus_hamatus)

[2] M.R. Siddiqi, "Tylenchida parasites of plants and insects," $2^{\text {nd }}$ eds, Willingford, UK, CABI Publishing, 2000.

[3] A.J. Thorsteinson, "Host selection in phytophagous insects," Annual Review of Entomology, 5, pp. 193213, 1960.

[4] Y.S. Rathore, S.S. Lal, "Phylogenetic relationships of host plants of Maruca vitrata," Indian Journal of Pulses Research, 11(2), pp. 152-155, 1998.

[5] Y.S. Rathore, S.N. Tiwari, "Phylogenetic relationships of whitefly, Bemisia tabaci Genn.," Journal of Plant Science \& Research, 1(3), pp. 110-115, 2014.

[6] Y.S. Rathore, S.N. Tiwari, "Influence of taxonomic diversity on host plant preference of different species of Bemisia," International Journal of Agricultural Sciences and Veterinary Medicine, 3 (2), pp. 50-63, 2015.

[7] Y.S. Rathore, S.N. Tiwari, "Host plant affinity with taxonomic groups in aphids- A case study," Global Journal of Biology, Agriculture \& Health Sciences, 4 (1), pp. 1-3, 2015a.

[8] Y.S. Rathore, S.S. Ali, "Relationships of root-knot nematode, Meloidogyne incognita, to taxonomic groupings of host plants," Trends in Bioscience, 7 (13), pp. 1562-1568, 2014.

[9] Y.S. Rathore, S.N. Tiwari, "Relationships of different species of Heterodera with taxonomic groupings of host plants," International Journal of Science \& Research, 4 (7), pp. 2269-2276, 2015b.

[10] Y.S. Rathore, S.N. Tiwari, "Relationships of species of Helicotylenchus with taxonomic groupings of host plants," Journal of Plant Science \& Research, 3 (1), 2016.

[11]Y.S. Rathore, S.N. Tiwari, "Relationships of different species of root-knot nematodes to their host taxonomic groups" International Journal of Plant 


\section{International Journal of Science and Research (IJSR) \\ ISSN (Online): 2319-7064}

Index Copernicus Value (2013): 6.14 | Impact Factor (2014): 5.611

Animal and Environmental Sciences (In Press), 6(2), 2016.

[12] Nemaplex, Nemabase Search Engine for the host range of genus and species of plant feeding nematodes, 2015. [Online]. Available: http://plpnemweb.ucdavis.edu/.../NematodeHostRang eQuery.aspx. [Accessed: February 27, 2015].

[13] J.M. Krupinsky, R.E. Barker, P.A. Donald, "Frequency of plant parasitic nematodes associated with blue gama and western wheatgrass in Western Dakota", Plant Disease, 67, pp. 399-401, 1983.

[14] J. Hutchinson, "Families of flowering plants," $3{ }^{\text {rd }}$ eds., Oxford at the Clarendon Press, 1973.

[15] F.A. Bernays, R.F. Chapman, "Host plant selection by phytophagous insects (Contemporary topics in entomology)," New York: Springer, 1994.

[16] H. van Megen, S.van den Elsen, M. Holterman, G. Karrssen, P. Mooyman, T. Bongers, O. Holovachov, L. Bakker, J. Helder, "A phylogenetic tree of nematode based on about 1299 full - length small subunit ribosomal DNA sequences," Nematology, 11, pp. 927-950, 2009.

[17]E. Van den Berg, L.R. Tiedt, S.A. Subbotin, "Morphological and Molecular characterization of several Paratylechus Micoletzky, 1922 (Tylenchida: Paratylenchidae) species from South Africa and USA, together with some taxonomic notes," Nematology, 16, pp. 323-338, 2014.

[18]E. Geraert, "The genus Paratylechus," Nematologica, 11, pp. 301-334, 1965.

[19]D.J. Raski, "Paratylenchus lepidus (Nematoda: Creconematoidea: Tylenchulidae)," Plant Pathology Bulletin, 16, pp. 41-46, 2007 


\section{International Journal of Science and Research (IJSR) \\ ISSN (Online): 2319-7064 \\ Index Copernicus Value (2013): 6.14 | Impact Factor (2014): 5.611}

Table 1: Affiliation of different species of Paratylenchus to host taxonomic groups

\begin{tabular}{|c|c|c|c|c|}
\hline Species & Host taxonomic groups & Host Plants & GAI & Status \\
\hline P. amblycephalus & Dicot-Lignosae: Rosaceae (3)- Cydonia sp., Malus sylvestris, Sorbus aucupareie & 3 & 1 & Oligophagous \\
\hline P. aquaticus & Monocot-Caly: Bromeliaceae (1) -Neoregelia sp. & 1 & 1 & Monophagous \\
\hline P. besoekianus & Dicot-Lignosae: Rubiaceae (2) - Coffea arabica, Coffea sp. & 2 & 1.333 & Monophagous \\
\hline P. conicephalus & Dicot-Herbaceae: Apiaceae (1) - Prangos ferulacea & 1 & 1 & Monophagous \\
\hline P. curvitatus & Dicot-Lignosae: Fabaceae (1); Dicot-Herbaceae: Asteraceae (2), Brassicaceae (1) & 4 & 0.667 & Polyphagous \\
\hline P. dianthus & $\begin{array}{l}\text { Dicot-Lignosae: Anacardiaceae (1), Rosaceae (1); Dicot-Herbaceae; Apiaceae (1), } \\
\text { Asteraceae (1), } \\
\text { Caryophyllaceae (1), Lamiaceae (3), Solanaceae (1); Monocot-Caly: Araceae (3), } \\
\text { Strelitziaceae (1); } \\
\text { Monocot-Glum: Poaceae (1); Gymnosperm: Pinaceae (1)- Tsuga sp. }\end{array}$ & 15 & 0.5 & Polyphagous \\
\hline P. elachistus & Dicot-Lignosae: Urticaceae (1) - Boehmeria nivea & 1 & 1 & Monophagous \\
\hline P. epacris & Dicot-lignosae: Fagaceae (1), Juglandaceae (1), Lauraceae (1) & 3 & 0.556 & Polyphagous \\
\hline P. halophilus & Dicot-Herbaceae: Chenopodiaceae (1)- Sarcocornia quinqueflora & 1 & 1 & Monophagous \\
\hline P. hamatus & $\begin{array}{l}\text { Dicot-Lignosae: Aquifoliaceae (1), Celastraceae (1), Cucurbitaceae (1), Ericaceae } \\
\text { (1), Fabaceae (5), } \\
\text { Fagaceae (2), Hydrangeaceae (1), Juglandaceae (1), Lauraceae (1), Magnoliaceae } \\
\text { (1), Malvaceae } \\
\text { (1), Moraceae (2), Myrtaceae (2), Oleaceae (2), Rosaceae (9), Rutaceae (1), } \\
\text { Salicaceae (1), } \\
\text { Theaceae (1), Vitaceae (12); Dicot-Herbaceae: Apiaceae (5), Asteraceae (2), } \\
\text { Brassicaceae (2), } \\
\text { Caryophyllaceae (1), Chenopodiaceae (1), Gesneriaceae (1), Lamiaceae (3), } \\
\text { Saxifragaceae (1), } \\
\text { Solanaceae (1); Monocot-Caly: Musaceae (1); Monocot-Corolli: Agavaceae (1), } \\
\text { Iridaceae (2), } \\
\text { Liliaceous (1); Monocot-Glum: Cyperaceae (1), Poaceae (3); Gymnosperm: } \\
\text { Pinaceae (2) - Picea sp., } \\
\text { Pinus sp., Polypodiaceae (1) - Polypodium sp. }\end{array}$ & 75 & 0.611 & Polyphagous \\
\hline P. labiosus & Monocot-Glum: Poaceae (1)- Zea mays & 1 & 1 & Monophagous \\
\hline P. macrophallus & $\begin{array}{l}\text { Dicot-Lignosae: Rosaceae (1); Dicot-Herbaceae : Asteraceae (2), Caryophyllaceae } \\
\text { (1), } \\
\text { Geraniaceae (1), Lamiaceae (2); Monocot-Glum: Poaceae (1) }\end{array}$ & 8 & 0.5 & Polyphagous \\
\hline P. microdorus & Dicot-Lignosae: Fabaceae (4); Monocot-Glum: Poaceae (6) & 10 & 1.2 & Polyphagous \\
\hline P. minutus & Monocot-Caly: Bromeliaceae (1); Monocot-Glum: Poaceae (1) & 2 & 0.667 & Polyphagous \\
\hline P. nainianus & $\begin{array}{l}\text { Dicot-Lignosae: Anacardiaceae (1), Moraceae (1), Myrtaceae (2), Rosaceae (1), } \\
\text { Rutaceae (2) }\end{array}$ & 7 & 0.529 & Polyphagous \\
\hline P. nanus & \begin{tabular}{|l|} 
Dicot-Lignosae: Fabaceae (4), Juglandaceae (1), Rosaceae (1); Dicot-Herbaceae: \\
Asteraceae (1), \\
Brassicaceae (1), Caryophyllaceae (1), Plantaginaceae (1); Monocot-Glum: Poaceae \\
(9); \\
Gymnosperm: Pinaceae (1)
\end{tabular} & 20 & 0.688 & Polyphagous \\
\hline P. nawadus & Dicot-Lignosae: Apocynaceae (1)- Carissa sp. & 1 & 1 & Monophagous \\
\hline P. neoamblycephalus & $\begin{array}{l}\text { Dicot-Lignosae: Fabaceae (4), Cucurbitaceae (1), Juglandaceae (1), Moraceae (1), } \\
\text { Rosaceae (6); } \\
\text { Dicot-Herbaceae: Apiaceae (1), Asteraceae (1), Caryophyllaceae (1), Solanaceae } \\
\text { (1); Monocot- } \\
\text { Glum: Poaceae (2); Gymnosperm: Pinaceae (1) - Pinus ponderosa }\end{array}$ & 20 & 0.564 & Polyphagous \\
\hline P. paraperaticus & Dicot-Lignosae: Juglandaceae (1)- Juglans regia & 1 & 1 & Monophagous \\
\hline P. projectus & $\begin{array}{l}\text { Dicot-Lignosae: Cucurbitaceae (1), Fabaceae (14), Malvaceae (1); Dicot- } \\
\text { Herbaceae: Apiaceae (1), } \\
\text { Asteraceae (3), Brassicaceae (5), Caryophyllaceae (2), Chenopodiaceae (2), } \\
\text { Gesneriaceae (1), } \\
\text { Solanaceae (3); Monocot-Corolli: Amaryllidaceous (1); Monocot-Glum: Poaceae } \\
\text { (42) }\end{array}$ & 76 & 1 & Polyphagous \\
\hline P. prunii & Dicot-Lignosae: Rosaceae (1) - Prunus persica & 1 & 1 & Monophagous \\
\hline P. sarissus & $\begin{array}{l}\text { Dicot-Lignosae: Fagaceae (1), Lauraceae (1), Rutaceae (1); Monocot-Glum: } \\
\text { Cyperaceae (1) }\end{array}$ & 4 & 0.5 & Polyphagous \\
\hline P. sheri & Dicot-Lignosae: Fabaceae (1) - Cicer arietinum & 1 & 1 & Monophagous \\
\hline P. similis & Dicot-Herbaceae: Asteraceae (1); Monocot-Glum: Poaceae (1) & 2 & 0.667 & Polyphagous \\
\hline P. straeleni & Dicot-Lignosae: Moraceae (1) - Ficus sp. & 1 & 1 & Monophagous \\
\hline P. tatae & Monocot-Glum: Poaceae (2) - Bromus sp., Lolium sp. & 2 & 1 & Oligophagous \\
\hline P. thornei & Dicot-Herbaceae: Apiaceae (1) - Daucus carota & 1 & 1 & Monophagous \\
\hline P. vexans & Monocot-Glum: Poaceae (2) - Agropyron smithii, Bouteloua gracilis & 2 & 1 & Oligophagous \\
\hline
\end{tabular}

Volume 5 Issue 3, March 2016 